\title{
A Sustainable Organic Production Model for "Food Sovereignty" in the United Arab Emirates and Sicily-Italy
}

\author{
Khalid Butti Al Shamsi ${ }^{1}$, Antonio Compagnoni ${ }^{2}$, Giuseppe Timpanaro ${ }^{1, *}$, \\ Salvatore Luciano Cosentino ${ }^{1}$ and Paolo Guarnaccia ${ }^{1}$ \\ 1 Department of Agricultural, Food and Environment, University of Catania, 95123 Catania, Italy; \\ kbalshamsi@gmail.com (K.B.A.S.); cosentin@unict.it (S.L.C.); paolo.guarnaccia@unict.it (P.G.) \\ 2 IFOAM AgriBio Mediterraneo Permanent Secretariat, c/o AIAB Emilia Romagna, \\ Casale Della Mora via Tavoni 20, 41058 Vignola, Italy; acompagnoni@database.it \\ * Correspondence: giuseppe.timpanaro@unict.it; Tel.: +39-095-7580-305
}

Received: 12 January 2018; Accepted: 23 February 2018; Published: 27 February 2018

\begin{abstract}
The aim of this research is to contribute to food security by studying the development of integrated organic production models related to the biodiversity of food sources, soil fertility and water availability, both in the United Arab Emirates (UAE) and Sicily. Using the FAO's multi-facetted approach of the Sustainable Assessment of Food and Agriculture Systems (SAFA) Tool, combined with interviews and visits to two organic farming communities in the UAE and Sicily, preliminary results were obtained consisting of: SAFA reports for each farmer and each community and the identification of some additional SAFA Tool indicators for local markets and migrant worker relations. Overall, the two systems contain elements described in the literature, such as Short Food Local Systems and as such contribute to territorial food support. Some best practices in organic production, direct marketing and migrant worker integration were identified and shared with farmers. The study highlights some operational issues that will be further focused upon in the future.
\end{abstract}

Keywords: organic agriculture; Sustainable Assessment of Food and Agriculture Systems by the FAO; short food supply chains

\section{Introduction}

Climate change, economic crises, migration flows, quality of life considerations and the impact on human health of consuming local resources destined for competition on the global market are increasing pressure for a movement towards pathways based on sustainability linked to specific local characteristics [1].

These processes have raised awareness among policy-makers and the public of the fragility of the global food system, to the point that the concept of "food security" is now widely developed but with different meanings between the term "food security" itself (the right of access of populations to food and drinking water), "food safety" (access to healthy food with no risks to human health and no contaminants) and "food sovereignty".

Food sovereignty is a political definition referring to a country's right to autonomously define its agricultural and food policies, as well as its patterns of production and consumption, in a socially fair and environmentally friendly way, thus enabling the citizens and inhabitants of an area to access sustainable food and promote the development of the area in which they live. This concept of food planning, which is a challenge that involves both developing and developed areas, ends up-within specific geographical contexts-being dependent on sensitivity towards and knowledge of sustainable consumption (with communicational activities that exploit transversal skills), on the promotion of 
"social innovation" processes regarding food (with the involvement of public administrations and civil society), on the co-production of innovative services (through co-decisional processes) and on the promotion of participatory forms of governance in order to develop agreed decisions to enable the achievement of well-defined public and private objectives [2,3]. These types of production models activate "Short Food Supply Chains (SFSCs)" that are taken into account by various stakeholders in defining economic development policies [4-6]. SFSCs thus represent a local agri-food policy model that is able to tackle the seriousness of the challenges posed by demographic trends and by the increase in global demand for food and fibre in a way that is compatible with the planet's food security strategies and with strategies for the protection of nature and biodiversity in land use. Organic agriculture also comes into play in this context for its ability to contribute to the conservation of the natural environment and to provide-in the short and long-term-diverse ecosystem services capable of producing additional environmental benefits compared to conventional agriculture (animal welfare and rural development, for example). Although the latter gives higher productivity levels per unit of land area (thus being apparently preferable to organic agriculture in terms of food security), it does not adequately respond to consumer demand for healthy and safe food and the need to maintain and increase the levels of organic matter in the soil [7].

Closely relevant to this process are the United Arab Emirates (UAE) and Sicily, linked by similar climate, demographic and migratory issues. Food security is an important issue for the UAE [8,9], since the country suffers from a lack of essential resources for agricultural activities-for example fertile soil, water for irrigation and labour skills $[10,11]$. This is countered by a proliferation of investment in infrastructure and economic activities (also in the tourism-hospitality sector, with more than 11,000 businesses-over 4000 in Dubai and 3000 in Abu Dhabi) which have attracted a high level of immigration (more than 200 ethnicities from all over the world) causing an increased demand for food that the country has tackled through imports. According to studies and research carried out by some leading international organizations (Economist Intelligence Unit), the UAE imports about $90 \%$ of its food products and finished foods, worth over USD 5.5 billion in 2015 (Table 1). The UAE also has one of the highest obesity rates in the world, to the point that policy makers have launched a series of countermeasures to combat food insecurity and to support healthier lifestyles and balanced diets. Recently, a new competitive environment has been created in which the government has sought alternatives in order to increase non-imported food production, concentrating on local farms (free grants of land to entrepreneurs who are willing to grow food crops; contributions of up to $50 \%$ of the cost of fertilizers and technical equipment; distribution of artificially cooled greenhouses; urban high-rise greenhouses for local food production; etc.), on new agricultural techniques and on organic farming in order to increase the sector's prosperity within the UAE [12-14].

Sicily, on the other hand, is a region rich in resources that are often under-exploited and undervalued, in which the population suffers from food insecurity and neighbourhood food access problems. According to official statistics, the average monthly spend by Sicilian households in 2015 totalled USD 1048.9, or 27\% of their total consumption; it also emerges that Sicilian households have reduced the quantity $(21.8 \%)$ and quality $(22.1 \%)$ of foods bought in the years following the economic recession. The region has a normalized import/export balance of $8.7 \%$ and a widespread adoption of organic agriculture with 363.6 thousand hectares (the top Italian region in this sense, with an incidence of $26.4 \%$ of the region's land area). Organic farming is the focus point of a spread in alternative forms of consumption such as ethical purchasing groups_-"Gruppi di Acquisto Solidale" (GAS)—which experiment with new social paradigms to promote sustainable development in rural areas through the active reorganization of the agricultural and food industry $[15,16]$. Other alternative consumption developments are also under way in Sicily to promote direct consumer-producer relationships, such as farmer's markets, an opportunity to spread and develop a correct, healthy food culture promoted by trade associations (CIA and Coldiretti), the Italian Organic Agriculture Association (AIAB), Legambiente and the Region of Sicily. 
Table 1. Main macroeconomic indicators on food insecurity and organic farming in the UAE and in Sicily $\left({ }^{a}\right)$.

\begin{tabular}{|c|c|c|c|c|c|c|}
\hline \multirow[b]{2}{*}{ Indications } & \multicolumn{3}{|c|}{ UAE } & \multicolumn{3}{|c|}{ Sicily } \\
\hline & Value & Period & Source & Value & Period & Source \\
\hline Total population, mns & 8.8 & 2016 & FAO & 5.0 & 2016 & ISTAT \\
\hline GDP per capita (USD) & $40,160.0$ & 2016 & FAO & $18,264.4$ & 2016 & ISTAT \\
\hline Surface, hectares & $98,577.0$ & 2015 & FAO & 1387.5 & 2015 & ISTAT \\
\hline Agri-food import, mio USD & 1417 & 2016 & FAO & 894.6 & 2016 & ISTAT \\
\hline Agri-food export, MIO USD & 338 & 2016 & FAO & 1199.6 & 2016 & ISTAT \\
\hline $\begin{array}{l}\text { Consumer expenditure per } \\
\text { capita on food and } \\
\text { non-alcoholic beverages (USD) }\end{array}$ & 3206.9 & 2016 & FAO & 5214.17 & 2016 & ISTAT \\
\hline $\begin{array}{l}\text { Average dietary energy supply } \\
\text { adequacy }(\%) \text { (3-year average) }\end{array}$ & 124 & 2014-2016 & $\mathrm{FAO}$ & & & \\
\hline $\begin{array}{l}\text { Number of severely food } \\
\text { insecure people, millions }\end{array}$ & 3.4 & 2014-2016 & FAO & & & \\
\hline $\begin{array}{l}\text { Average dietary energy supply } \\
\text { adequacy (\%) (3-year average) }\end{array}$ & 146 & 2014-2016 & FAO & & & \\
\hline Organic Surface, ha & 4286 & 2015 & IFOAM & 363,639 & 2016 & SINAB \\
\hline Organic share, $\%$ & 1.1 & 2015 & IFOAM & 26.4 & 2016 & SINAB \\
\hline Producers, n. & 53 & 2015 & IFOAM & 9543 & 2016 & SINAB \\
\hline Processor, n. & 6 & 2015 & IFOAM & 1890 & 2016 & SINAB \\
\hline Exporters, n. & 7 & 2015 & IFOAM & 0 & 2016 & SINAB \\
\hline Importer, $\mathrm{n}$. & 0 & 2015 & IFOAM & 18 & 2016 & SINAB \\
\hline $\begin{array}{l}\text { Health \& wellness product } \\
\text { consumption (USD) }\end{array}$ & 1338.9 & 2016 & $\begin{array}{c}\text { Economist } \\
\text { Intelligence Unit }\end{array}$ & & & \\
\hline $\begin{array}{l}\text { Organic packaged food and } \\
\text { beverage consumption (USD) }\end{array}$ & 21.9 & 2016 & $\begin{array}{c}\text { Economist } \\
\text { Intelligence Unit }\end{array}$ & & & \\
\hline
\end{tabular}

(a) Our processing. Rate change EUR/USD 1 EUR = 1.0701 USD.

Ultimately, therefore, these are two territories with many similarities and issues in terms of climate (mild winters, hot/scorching summers and drought), demography (net migration rates among the highest in the world), the economic-social environment (management of migratory flow and consequent issues of security, social stability and nutritional needs) and food (high import levels, also to cope with an internal demand that varies in quality and quantity). A solution to these issues can be found by adopting a sustainable agricultural development model such as organic farming, which can respond to several political-institutional, social, environmental and nutritional needs through an approach focused on local autonomies and markets and on the crucial factors required for communities to produce food locally (sustainable land and water use and agro-biodiversity, for example).

At the international level the role of organic agriculture in the development of local economies is acknowledged for its ability to bring about an increase in local income per capita, improving the quality of life for entire areas and creating local markets for sustainable agricultural products $[17,18]$. A knowledge of these production systems and the sharing of know-how from these farmers thus enables the development of innovative approaches to sustainable development and food security that is more bio-diverse, resilient and socially fair.

For this reason, use has been made of the SAFA (Sustainability Assessment of Food and Agriculture systems) application-developed by the FAO and consisting of a set of indicators for holistically (environmental, social, economic and cultural) measuring the sustainability of the various production processes-to provide technical support for decision-making processes.

The general objective of the work is to analyse the relationship between sustainability, food safety, food sovereignty (local/regional) and organic production practices in the geographical areas studied through empirical analysis.

On the one hand, possible suggestions will thus be outlined for policy makers who are planning action to foster the sustainable development of territories by promoting organic agriculture and, on the 
other, proposals will be made for the possible implementation of the SAFA tool in order to exploit this more extensively.

The text is thus organized: begins with a review of the literature on keywords such as sustainability, food security and sovereignty and tools for the measurement of sustainability. Then continues by connecting the goals of socio-economic development of the territory with the adoption of the organic farming model, to reach a sustainability in holistic key. This part is made using the framework SAFA of FAO. Concludes with finding "SFSCs", as an instrument of support to food sovereignty.

\section{Review of the Literature on Measuring Sustainability and Food Sovereignty}

The link between measuring sustainability and food security in its different definitions has lost the former sharp demarcation between rich and poor countries and now applies transversally across the various territories and areas of the planet; this is also a result of wealth reallocation processes between countries and social groups and of more widespread urbanisation. An urban food security dimension has therefore been defined-using an approach that balances economics, the environment and population dynamics - which has fuelled discussion on the themes of technological revolution, new patterns of productive intensification, local production, sustainable diets from the environmental and human health point of view, waste reduction, mitigation of the impact of agri-food chains on waste produced, etc. SAFA has also been used to analyse urban food policy and food planning processes in order to achieve sustainable food security, with applications in some urban contexts that over the past few years have launched strategies for the development of healthier and more sustainable food systems [19].

Another SAFA application has been used to assess the performance of local food chains compared to the global chains, based on the increased awareness among consumers of the impacts of their choices. Some key attributes of SAFA have been selected regarding the supply chains for wheat and its by-products and a participatory approach has been used to explore the perspectives of different stakeholders on sustainability $[20,21]$. In Canada, on the other hand, a study has been made of the ability to affect agricultural development of social groups that are committed to sustainability in terms of water, climate change and the agricultural landscape. SAFA has thus been used to show how farmers adapt their strategies both collectively and individually (e.g., socially through the improvement of working conditions; environmentally through soil conservation; innovatively by experimenting with new practices thanks to public funds and the exchange of knowledge) to take account of social needs [22]. In Austria, moreover, a study demonstrated the ability of small organic farms and local food systems, which are economically and socially resilient, to achieve a significant socio-economic and ecological performance. This offers inspiration for new, innovative and small-scale approaches that can contribute to the transition to sustainability [23].

The correlation between sustainability and food security in Italy [24] is linked to attitudes regarding ecological factors (such as climate change, soil pollution and erosion), the market (food products should circulate freely to achieve comparative advantages and bring their price down), quality (underlining the link between food production, geographical areas and cultural traditions), social factors (socio-economic inequalities and social marginalization), solidarity (specific assistance programmes for individuals, families and groups), sovereignty (so that local/regional communities can assert their right to control their own food systems in order to reduce food insecurity and vulnerability), trust in technology (which must serve to improve production efficiency and food security) and health (personal consumption choices).

The concept of "food sovereignty", therefore, has slowly asserted itself, as demonstrated by the large amount of literature on this subject-although a uniform conceptualization does not yet exist. The different studies analyse aspects related to the "right of nations" (self-sufficiency in food production), the "right of the peoples" (local self-sufficiency), the role of women and disadvantaged people in building food self-sufficiency, the freedom of farmers to democratically choose the species that they grow, gender equality and the role of family-run agriculture and collective and individual rights aimed 
at promoting social equality and democratic choices [25]. The identification at international level of new attitudes towards food production and consumption has led to a quest for new organisational forms based on increasingly close cooperation between producers and consumers; this goes beyond the simple dimension of economic exchange and, to an increasing extent, makes reference to shared objectives of social and environmental sustainability. This phenomenon ends up also including specific social mobilization initiatives through the creation of networks with broader objectives to change lifestyles and development models [26]; in the literature, these are known as "Short Food Supply Chains (SFSCs)" and are aimed at re-gaining a more direct control over food and its multiple implications [27-29].

In this context, alternative and local food supply chains become a driver of regional development via an increase in food security at the local level. Peri-urban agricultural entrepreneurs have, among other things, adopted strategies to hybridise conventional and alternative food chains (according to the proportion of products allocated to the local market, personal and professional ties, the diversification of the sales network and the assortment of products sold through SFSCs), contributing to the characterization of the range of products available locally and with benefits for community food security [30].

\section{Materials and Methods}

A number of international studies have demonstrated the link between food security, resilient production systems and agricultural models based upon concepts of agro-ecology [31,32]. Of the latter, organic agriculture is central to the development of large initiatives in certain regions of Asia, Africa, Latin America and Europe, in the context of production systems made up of small landowners, family-run farms and those producing for the local internal market. These existing systems based on organic farming become models for resilience and for the ability to counteract the universally recognised effects of climate change and financial crises [33]. These findings, which have been predominantly observed in developing countries, can also be detected using different approaches in countries with advanced economies [34,35]. These countries, indeed, find themselves facing the same emerging issues at international level, with concern arising from the pressure of conflicting interests linked to the predominance of intensive and industrialized agricultural models. Organic farming is, nonetheless, practised in all countries throughout the world and is becoming increasingly widespread, above all in some areas. For these reasons, two areas have been chosen within the context of advanced economies: Sicily, which is the leading region in Italy in terms of organic investment and the United Arab Emirates, where significant growth has been recorded in organic production due to a specific interest in the food safety model offered by this system.

The research methodology adopted a holistic approach to study sustainability among a set of selected farms in the UAE and Sicily, using the SAFA system and Tool implemented by the FAO. The SAFA Tool (version 2.2.40) (FAO, Rome, Italy) is an open source, freely-available and user-friendly software package offered by the FAO to implement the SAFA Guidelines (version 3.0) (FAO, Rome, Italy) and the SAFA indicators for assessing the sustainability of enterprises [36]. The SAFA protocol for selected companies or sectors is designed to be a process based on guidelines, codes of sustainability, self-assessment forms, operational plans, calculation methodologies and a system of indicators for the assessment and continuous monitoring of the business management situation. The SAFA assessment is carried out on the basis of a series of dimensions, themes, sub-themes and indicators, as shown in Table 2 [37]. This is very important to be able to define the areas in which intervention is needed to improve the impact of actions on the two geographical contexts analysed in the study (Sicily and the United Arab Emirates).

The SAFA Tool was integrated with specific questions in order to collect the data and information needed in comprehensively defining the three pillars of sustainability (environmental, social and economic). The aim was also, as much as possible, to adopt a holistic approach to prepare additional proposals and/or to improve the SAFA Tool designed by FAO and enable its wider application. 
Table 2. General structure of SAFA-FAO.

\begin{tabular}{cc}
\hline Dimension “Good Governance" & Dimension “Environmental Integrity" \\
\hline 5 Themes & 7 Themes \\
14 Sub-Themes & 14 Sub-Themes \\
19 Indicators & 52 Indicators \\
\hline Dimension “Economic resilience" & Dimension “Social Well-Being" \\
\hline 4 Themes & 6 Themes \\
14 Sub-Themes & 16 Sub-Themes \\
26 Indicators & 19 Indicators \\
\hline
\end{tabular}

Besides applying the multi-facetted sustainability approach of environmental, economic and social health, specific emphasis was given to understanding the degree of sustainability in the production of food for the local market, identifying what is needed and how to promote it and assessing its contribution to a stable food supply.

The opinion-leading farms were selected by convenience sampling, using quota-based judgmental sampling methods. This approach was chosen due to the recent advent of organic agriculture in the United Arab Emirates and the still limited number of producers operating (54 in 2015). To define the quotas, reference was made to the representative characteristics of farms among the population reported in the main international statistical source (IFOAM). Stratification factors chosen for the selection of farms were therefore: production location address, agro-ecological approach in managing the production system, entrepreneurial characteristics and the desire to produce positive externalities (e.g., soil fertility, increase in spontaneous flora and fauna, management of hydro-geological instability, water protection, landscape protection/creation/management, containment of the effects of climate change) and the supply of products to the local market.

Two groups of farmers were selected in the two territories, 8 farmers per region, 7 of which certified as organic according to EU production regulations regarding: open field and greenhouse vegetables (Sicily and the UAE); fruit, dates (UAE only); citrus fruits and ancient cereals (Sicily only); and livestock (mainly goats, sheep, chicken and honey). All but one farm (in Sicily, with integrated pest management and no herbicides or synthetic fertilizers, producing summer fruit and grapes for wine) shared the characteristic (to varying degrees) of directly marketing their products to the local market. All of the farms had migrant workers.

Direct interviews and SAFA Tool assessments were carried out at all the farms, collecting a great deal of information and data (fieldwork carried out from January to September 2017). Some of the data collected was confirmed by organic and ethical certification, some was verified by the researchers, while other data relied (for the time being) on the statements of the farmers. Interviews with migrant workers were carried out together with an analysis of the legal and practical situation of migrant workers in the two regions. The relevance of the Organic 3.0 research approach can be seen in the all-round sustainability approach and the special focus on food security/food sovereignty, local markets and the integration of migrant workers. Last but not least is the fact that the research itself facilitated the development of organic farmers' communities and the sharing of best practices.

The assessment of the connection between food sustainability and sovereignty was carried out by extrapolating all the possible indicators able to represent this aspect of food security. In particular, the indicators belong to all four of the sustainability dimensions identified by the FAO in order to build the holistic approach assessed by SAFA and regard aspects of the guarantee of production levels, the existence of local biodiversity, the connection with the market (also through hybrid, local and global approaches), gender equality, the dialogue with stakeholders, etc., as shown in Table 3. 
Table 3. SAFA indicators considered for the assessment of food sovereignty in Sicily and the United Arab Emirates (2017) $\left(^{\mathrm{a}}\right)$.

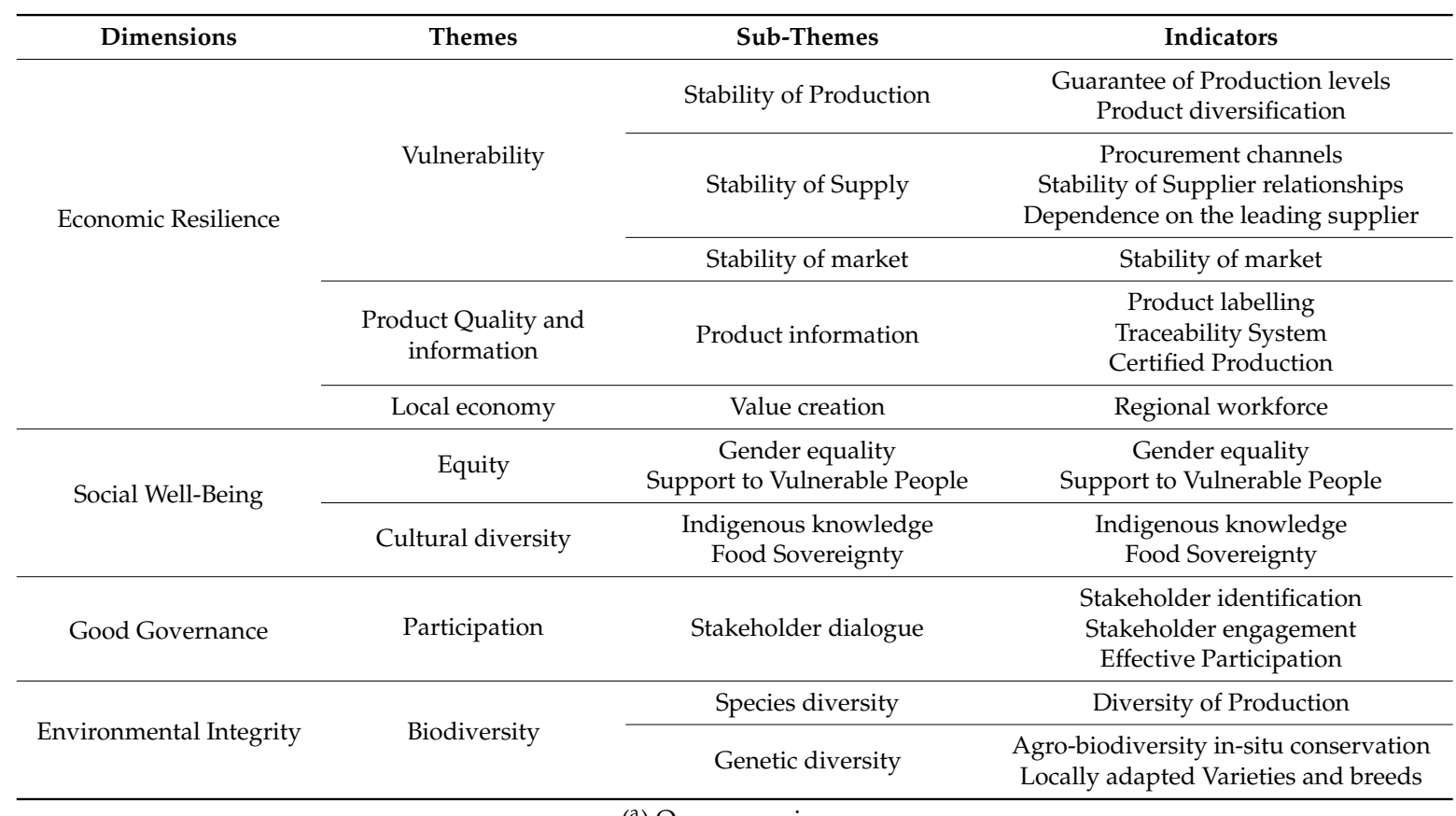

$\left({ }^{\mathrm{a}}\right)$ Our processing.

Based on the SAFA methodological approach, a rating is processed for each indicator ranging between "Best" (80-100\%), "Good" (60-80\%), "Moderate" (40-60\%), "Limited" (20-40\%) and "Unacceptable" (0-20\%), at a level of data reliability ranging between a score of " 1 - High quality data" (for current data collected for SAFA or other sustainability measurement audits), "2-Moderate quality data" (for secondary or two year-old data) and "3-Low quality data" (for estimates or data over five years old). The SAFA system, finally, processes the data directly and outputs a series of graphical summaries.

\section{Results}

\subsection{Placing of the Sample within Short Food Supply Chains}

The farmers' sample surveyed shows some of the distinctive characteristics found in the literature with reference to Short Food Supply Chains (Table 4). In all cases, farmers are engaged in the local market through direct sales on the farm and at farmers' markets within a $150 \mathrm{~km}$ geographical radius, encouraging direct interaction with the end consumer based on trust and the assured use of organic production methods.

The result is that, in all cases, the multifunctional farms identified in Sicily and the UAE are involved in the production of fresh products and/or products with limited processing; these are placed on the local and global markets also using a hybrid approach, paying real attention to the safeguarding of all local parameters: social, cultural, economic and environmental. For producers, the benefits of participating in an SFSC are often higher prices and/or a greater assurance of successfully selling their products. In any case, companies operating through "SFSCs" are all subject to an identification and monitoring system set up by forward market operators and/or consumer networks.

An important role in the process of entering the market is played on the one hand by local institutions that are willing to support direct sales initiatives, and, on the other, by ICTs (social media and tools such as Facebook, Instagram and WhatsApp)—which are a powerful tool for engaging with potential buyers. The latter are made up of end-users and intermediate buyers (small restaurant/catering businesses, small urban retailers, local markets, collective sales outlets, organised 
supply and demand groups, ethical purchasing groups, sales within companies, group catering), based on geographical and also organisational proximity.

Table 4. Specific cases of SFSCs in Sicily and the UAE (2017) $\left(^{a}\right)$.

\begin{tabular}{lll}
\hline \multicolumn{1}{c}{ Indications } & \multicolumn{1}{c}{ Sicily } & \multicolumn{1}{c}{ UAE } \\
\hline Type & $\begin{array}{l}\text { Individual and/or networked farmers } \\
\text { under the guidance of political, social, } \\
\text { ethical and corporate coordination (trade } \\
\text { associations) }\end{array}$ & Group of farms \\
\hline $\begin{array}{l}\text { Direct selling of food products to } \\
\text { consumers on line and at farmers' markets } \\
\text { Adoption of FAO's SAFA Holistic } \\
\text { Sustainability Measurement System }\end{array}$ & $\begin{array}{l}\text { Direct selling of food products to } \\
\text { consumers at farmers' markets } \\
\text { Adoption of the FAO's SAFA Holistic } \\
\text { Sustainability Measurement System }\end{array}$ \\
\hline $\begin{array}{l}\text { What is meant by } \\
\text { short? }\end{array}$ & $\begin{array}{l}\text { Direct from farmers to consumers } \\
\text { Direct delivery to consumers of mostly } \\
\text { regional products (contact to producer } \\
\text { through ICT and direct) }\end{array}$ & Direct from farmers to consumers \\
\hline $\begin{array}{l}\text { Health and food } \\
\text { quality }\end{array}$ & $\begin{array}{l}\text { Freshness (good access to broad variety, } \\
\text { especially vegetables and fruits) } \\
\text { Seasonal }\end{array}$ & $\begin{array}{l}\text { Freshness (broad variety) Good taste } \\
\text { Seasonal }\end{array}$ \\
\hline $\begin{array}{l}\text { Sustainability aspects } \\
\text { Growth and } \\
\text { development }\end{array}$ & $\begin{array}{l}\text { Local food, (few food miles) Organic farms } \\
\text { Innovative elements }\end{array}$ & $\begin{array}{l}\text { Local, seasonal (few food miles) Organic } \\
\text { farms }\end{array}$ \\
\hline $\begin{array}{l}\text { Fonsumer comes to know the identity of } \\
\text { producers through website, Facebook, } \\
\text { WhatsApp }\end{array}$ & $\begin{array}{l}\text { An increase in the area invested in organic } \\
\text { farming is underway }\end{array}$ \\
\hline
\end{tabular}

$\left({ }^{a}\right)$ Our processing adapted from [38]

Their willingness to measure their sustainability level through the SAFA approach strengthens the ethical dimension through which their business activity is conducted. This demonstrates the extent to which the farmers are committed to achieving a vision with environmental, social, ethical and economic dimensions in the area within which they operate. As has been observed in the literature, organic agriculture in the context of "SFSCs" contributes to an improvement in the natural, human, social, physical and financial capital of the rural communities in which these exist [39]. The participation of the institutions and the will expressed by consumers through their buying behaviour demonstrate a local desire to adopt a participatory type of agro-food planning process based on the quality of the product, a desire to support the local economy, proximity between the places of production/consumption and the search for higher levels of quality and healthiness in agri-food products. Moreover, the SFSCs identified implicitly possess a characteristic: that of being promoters of the processes of active citizenship and local transformation by actively redefining the relationships between food and local area, producer and consumer, town and country, nature and agriculture [40].

It is interesting to note that organic products are often the trigger in moving towards a healthy lifestyle, which then ends up also involving other sectors and products looked for on the market. SFSCs, therefore, which revolve around the organic agro-food sector, often become the key element in the promotion, integrated support and development of an area, which then spreads from agro-food to other sectors, allowing its participants to become aware of the consequences of their choices on all the elements of the area that they belong to.

\subsection{General Characteristics of the Organic Farms Sample}

Altogether, the farms surveyed have an organic land area of between two and 320 hectares, with an average of approximately 55 hectares. Sicily has a larger average farm size (Table 5). As stated, 
the whole sample is involved in primary production with local direct sales for between $50 \%$ and $80 \%$ of products, with a tradition in organic production in some cases (in Sicily) of over twenty years.

Table 5. Main characteristics of organic farms in Sicily and the United Arab Emirates (2017) ( $\left.{ }^{a}\right)$.

\begin{tabular}{|c|c|c|c|}
\hline Indications & n. & Indications & n. \\
\hline$\frac{\text { Localization, } \mathrm{n} .}{\text { - United Arab Emirates }}$ & 8 & $\begin{array}{l}\text { Permanent workers, } \mathrm{n} \text {. } \\
\text { - Family workers }\end{array}$ & \\
\hline - Sicily & 8 & $\begin{array}{l}\text { - No units } \\
\text { - Up to } 3 \text { units }\end{array}$ & $\begin{array}{l}8 \\
7\end{array}$ \\
\hline Range of Total surface & & - Over 3 units & 1 \\
\hline - up to 30 ha & 9 & - Non Family workers & \\
\hline-30 ha to 100 ha & 4 & - No units & \\
\hline - over 100 ha & 3 & $\begin{array}{l}- \text { Up to } 3 \text { units } \\
-3 \text { to10 units }\end{array}$ & $\begin{array}{l}4 \\
6\end{array}$ \\
\hline Production typologies & & - Over 10 units & 6 \\
\hline - specialized single-crop company, n. & 2 & & \\
\hline - multi-crop company specialized in plots, $\mathrm{n}$. & 14 & $\begin{array}{l}\text { Temporary workers, } \mathrm{n} \text {. } \\
\text { - Family workers }\end{array}$ & \\
\hline Types of production, $\%$ & & - No units & 15 \\
\hline - Citrus fruits & 11.4 & - Up to 3 units & 1 \\
\hline - Vegetables & 34.3 & - Over 3 units & 0 \\
\hline - Cereals & 11.4 & - Non Family workers & \\
\hline - Fresh fruit & 5.7 & - No units & 7 \\
\hline - Dried fruit & 5.7 & - Up to 3 units & 3 \\
\hline - Grapes and wine & 2.9 & -3 to 10 units & 3 \\
\hline - Legumes & 2.9 & - Over 10 units & 3 \\
\hline - Olives and oil & 2.9 & & \\
\hline - Livestock farm & 20.0 & & \\
\hline - Grazing & 2.9 & & \\
\hline
\end{tabular}

$\left({ }^{\mathrm{a}}\right)$ Our processing.

There is a great diversity of vegetable crop production, including some perennial fruit (citrus fruit and almonds in Sicily, dates in the UAE); green manuring and the use of compost are some of the best practices identified by the research, giving farms a more stable environment both agronomically and economically.

The integration of livestock breeding (sheep, goats and cattle in Sicily, sheep, goats, chickens and camels in the UAE) with vegetable production, either on the same farm or in collaboration with neighbouring farms, was identified as a best practice, reducing off-farm input and, when directly managed by the same farm, increasing the product range (dairy products, meat and eggs) available for the local market.

Farms in the two contexts analysed recorded a progressive increase in productivity over time (which had sharply declined during the period of conversion to organic) as well as in natural capital (soil fertility, level of agrarian biodiversity for the cultivation of more species, etc.).

Non-family workers predominate in farm operation, ranging from a minimum of 1 to a maximum of 55 employed as "permanent workers" and between a minimum of 0 and a maximum of 30 as "temporary workers." In all cases the average amount of human capital is high and averages 12 and 10 units respectively for the two types.

Some of the farmers in Sicily take part in a regional programme, Sicilia Integra (an initiative developed by Gaia Education and the University of Catania in partnership with the Don Bosco 2000 and I Girasoli migrant welcome centres, organic farmers' cooperatives and European ethical organic food companies) that can be identified as a best practice and through which migrants and refugees receive training on organic farming and sustainable development, including a period of internship on organic farms. The programme also actively promotes this approach in the market, enhancing 
the profile of the organic producers participating in the programme. Sicilia Integra aims to support the socio-economic integration of migrants arriving in Sicily through sustainable community and agro-ecology capacity building activities, with the aim of creating an alternative trading platform for the marketing of Sicilian organic products in European markets. The project also aims to foster professionalization among migrants and unemployed young people, to create new work opportunities in regenerative agriculture and to contribute to the development of a circular economy in Sicily.

The work inclusion model proposed by Sicilia Integra and adopted by some farms in the sample can also constitute a model of best practice for the UAE. The two areas suffer from illegal immigration issues that are driven partly by the need for social and political survival (from countries such as India, Pakistan and Bangladesh to the UAE and from Nigeria, Senegal and other African countries to Sicily) and partly by the quest for work opportunities. Due to the huge flow of immigration, conditions often arise that favour employment in low-cost manual production activities, often in violation of workers' and human rights. To counter these phenomena, agriculture is called upon to play a role in combating social exclusion-particularly in relation to vulnerable groups such as minorities and the immigrant population-thus contributing to the concept of sustainability in a holistic sense.

\subsection{Results of the Farmers' Sustainability Assessment Process Measured by the FAO SAFA Tool}

A first SAFA Tool assessment result for each farm was obtained, as well as one summarizing each farmers' community with the relevant average scores (Figure 1). Additional indicators for the SAFA Tool were identified for the local market based on volumes, turnover and the number of different products marketed directly by the farms.

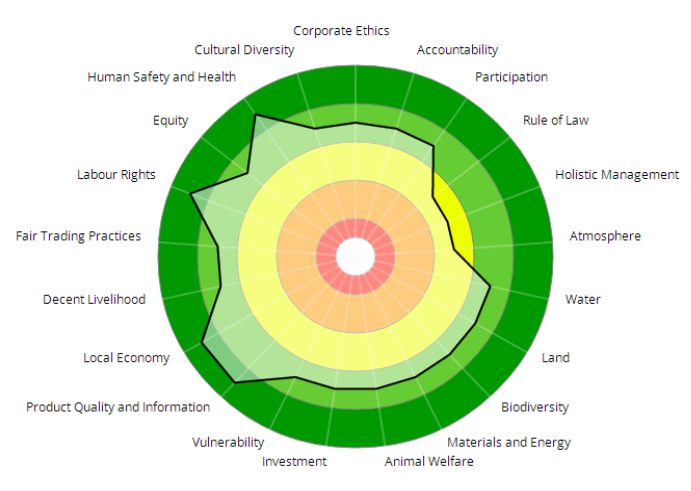

(a)

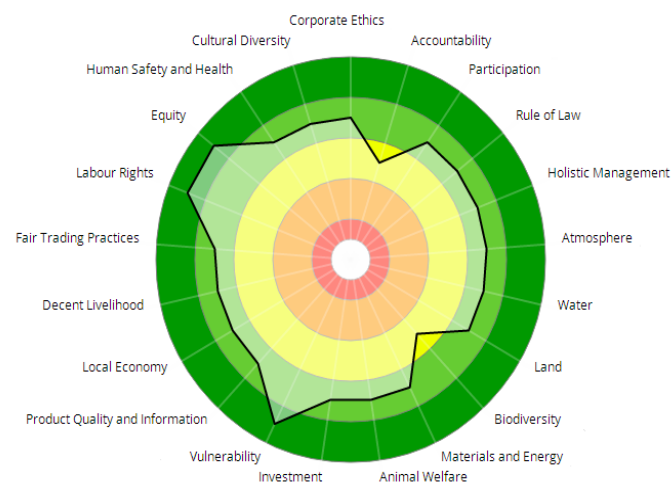

(b)

Figure 1. SAFA polygons that identify the two farmer communities with their average scores (2017). (a) Farms in Sicily; (b) Farms in UAE.

Overall, the macro-indicators assessed show positive scores for the two areas studied, with higher ratings for aspects such as "Human Safety and Health", "Labour Rights", "Local Economy", "Product Quality and Information" in Sicily and "Equity", "Labour Rights" and "Vulnerability" in the UAE. All of these indicators show performance scores ranging from 80 to 100 per cent (intense green area). These five indicators refer to two sustainability dimensions- "Economic Resilience" ("Product Quality and Information"; "Local Economy"; "Vulnerability") and "Social Well-Being" ("Human Safety and Health"; "Labour Rights") — that are directly connected with the general objective of the research, demonstrating relations with sustainability and food security, food sovereignty and organic farming practices.

There is a certain variability within different production sectors in the two geographical areas considered (Figure 2). Although both have high levels of sustainability, for the "vegetables and fruit" and "vegetables and livestock" farm categories (chosen for their relative importance in the two geographical areas), the comparison reveals more well-established skills and know-how in the case of 
Sicily, which can boast a long tradition in organic farming matched by greater capital resources and, therefore, more technology to support investment in the productive processes.

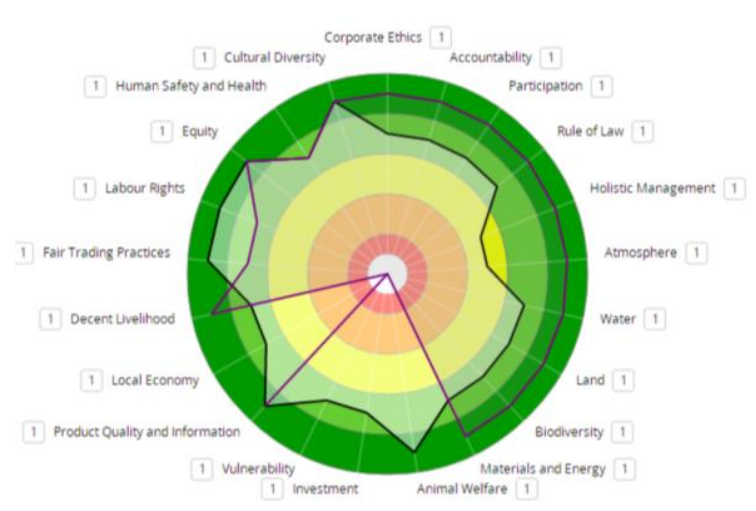

(a)

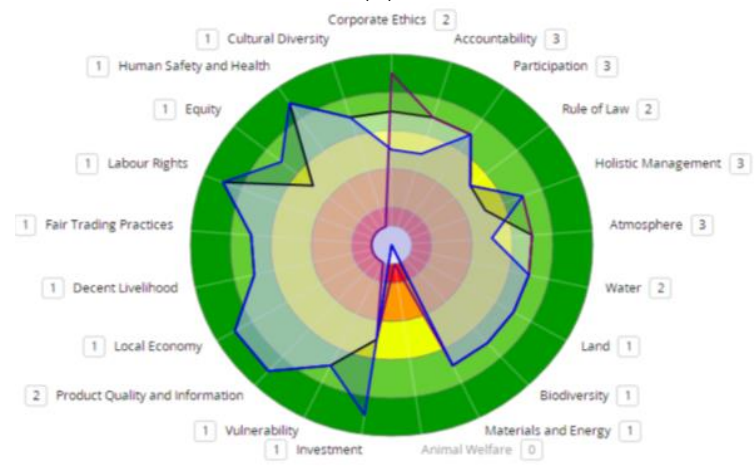

(c)



(b)

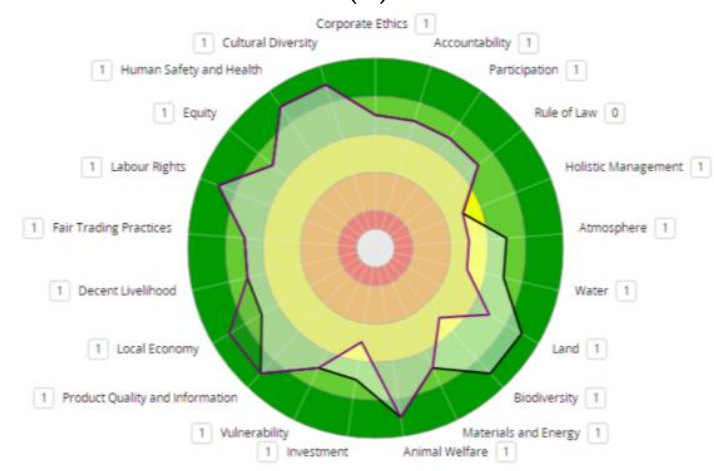

(d)

Figure 2. Comparison between levels of sustainability in in farms with "vegetables and fruit" and "vegetables and livestock" in the UAE and in Sicily (2017). (a) Vegetables and Fruit in the UAE; (b) Vegetables and Livestock in the UAE; (c) Vegetables and Fruit in Sicily; (d) Vegetables and Livestock in Sicily.

Economic resilience indicators are closely linked to labelling, certification, origin, production method or value-based production system identification, etc., so that consumers can make a real choice [41,42]. These are increasingly extensive processes throughout the food supply chain, with independent and collaborative verification systems, which take on increasing importance in consumer interest and the growth of the relevant market and are perfectly in-line with the organic certification system.

Support for the local economy by the enterprises surveyed was measured in terms of their ability to employ skilled labour from the micro-environment in which they operate (community, region). Indeed, local employment is seen as a valuable tool in providing value creation, support for the progression and upgrading of skills and investment in education and training, since employment and sustainable economic development are very much mutually interconnected [43].

Other local development indicators are linked to: (1) Respect for the country of origin's tax obligations, a factor thought indispensable for the communities themselves to be able to offer high-value public services such as infrastructure, security, transport, electricity, healthcare, education, environmental protection and, ultimately, a share of the social capital available to the enterprise; (2) the ability of enterprises to benefit from local economies through participation in supply contracts that act positively on the institutional social capital available to businesses and on food security by reducing imports to the territory through investment, skills development and trade relations. 
Moving in this latter direction, in Sicily, are numerous food education programs launched also with the support of the European Action Plan for Organic Farming (e.g., "Fruit in Schools") [44-46].

The "Social Well-Being" dimension focuses mainly on health and safety training at workplaces and vocational training and qualifications.

Factors that need improvement to increase the level of business sustainability of the two production systems considered are the Rule of Law, Holistic Management and Atmosphere in Sicily and "Biodiversity" and "Accountability" in the UAE.

Problems in Sicily regard operational legitimacy, assessed by the enterprise's adherence to the rule of law by adopting international voluntary codes, corporate missions and risk aversion as well as sustainability planning capabilities, integrating values or specific plans for the definition of environmental impact reduction targets (in percentages, total, etc., for each production unit).

In the UAE, problems are connected with the ability to maintain or improve complex ecosystems, given the climatic aridity, management difficulties and the need for ecosystem services that can respect semi-natural habitats and safeguard biodiversity. Finally, a lack of holistic approaches is addressed by SAFA through its ability to monitor all areas of sustainability via its dimensions for the environment, the social context, the economy and governance; this is particularly useful in reporting on the sustainability of enterprises.

\subsection{The Contribution of Short Food Supply Chains to Food Sovereignty}

Within the group of indicators measured by the FAO's SAFA Tool, one part is devoted to the "Food Sovereignty" indicator. It appears in the "Social" dimension and in the "Cultural Diversity" theme, aimed at understanding the extent to which the need is perceived for a more just, local and sustainable food system that represents the fundamental values of democracy and self-determination. Food sovereignty involves the creation of an ecologically harmonious and local food and agriculture system derived from the right of peoples and communities to define it.

At the macroeconomic policy level (which includes indicators regarding patterns of ownership and production in communities of different ethnicities and types, both rural and urban), this theme is applied at the individual enterprise level using indicators to detect its independence and capacity for autonomy and control over its production and supply systems (availability of inputs and knowledge rooted in the collective memory, such as species and varieties, availability of seeds, animal breeds, etc., ability to penetrate the local market), as well as choices that reinforce this independence (freedom) from other operations [47,48].

For this reason, the range of indicators conventionally used by SAFA has, as mentioned, been integrated into the methodology, within the two "SFSCs" considered in the United Arab Emirates and Sicily (Figure 3).

There are some background differences emerging in the comparison related to the level of development of local economic systems and the level of awareness reached by the various stakeholders operating in the two geographical areas.

The United Arab Emirates, with high levels of economic development, has a per capita income of $\$ 67,600$ (ranked 7th in the world) and high investment in technology and innovation, as well as a need to achieve adequate levels of food security [49]. In order to counter the arid environmental conditions, the past few years have witnessed an increase in the level of local political interest and openness towards organic farming, anticipating the needs and demands of the most advanced part of the market. In this country, the perception of the issue of food security in terms of sovereignty appears well-defined, even more so than in Sicily. 


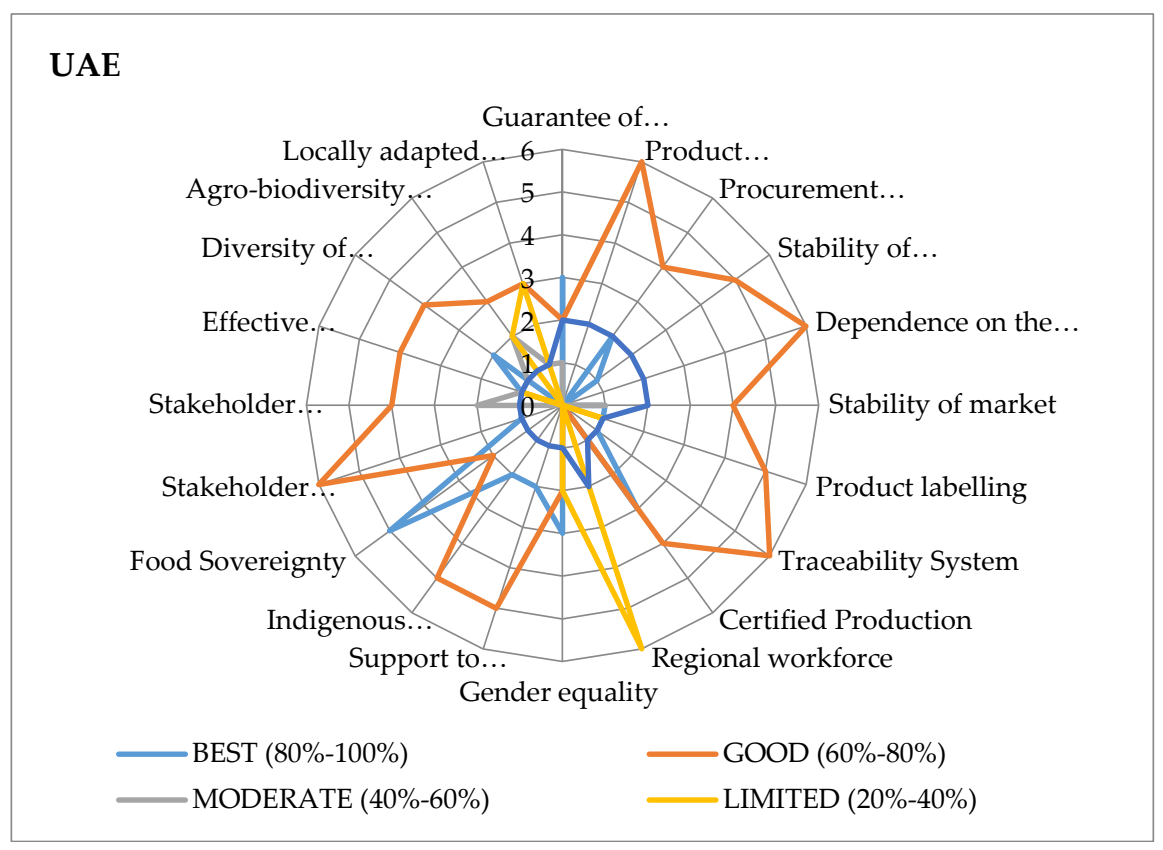

(a)

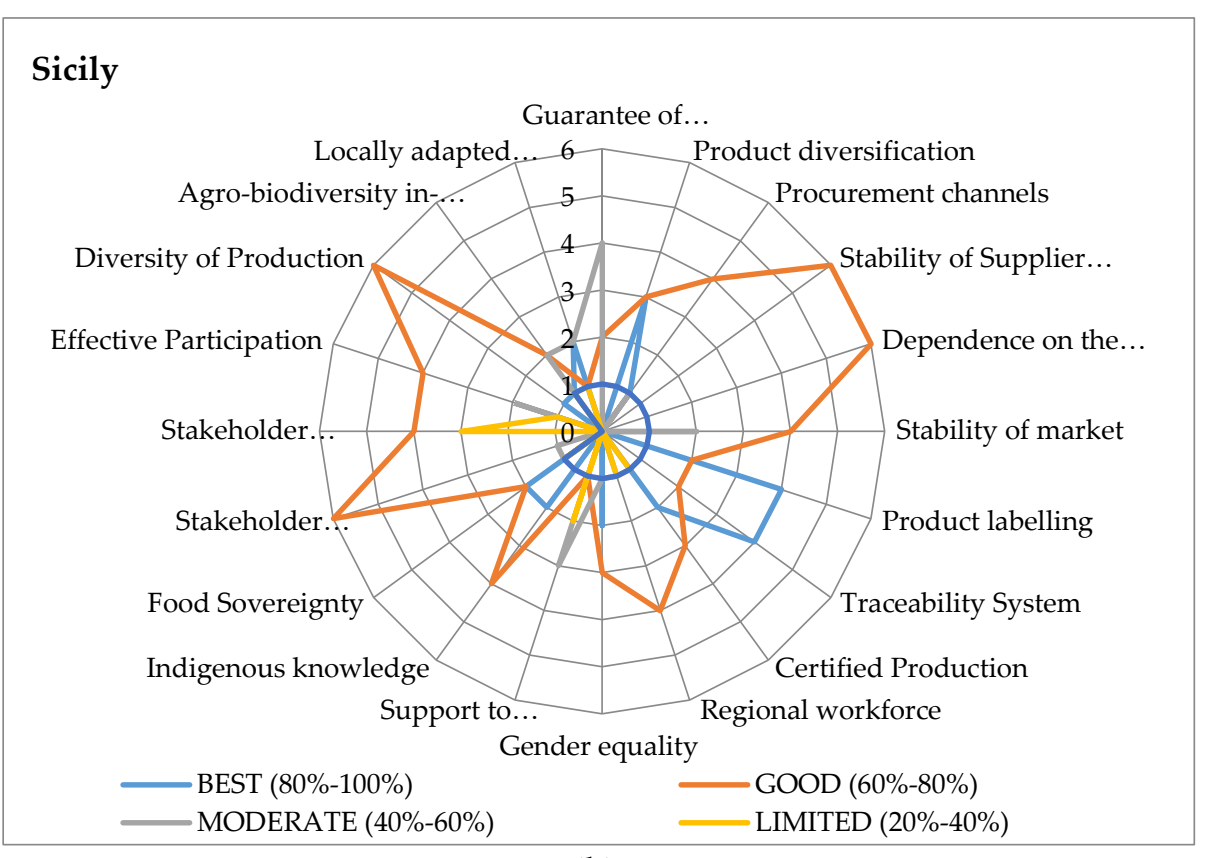

(b)

Figure 3. Comparison between the levels of "Food sovereignty" found in Sicily and the UAE (2017). 
Sicily is a land rich in contradictions and shows strong differences between local development levels that are often not in-line with the trend shown in other areas of Italy [50]. Among the many contradictions are a great sensitivity to the adoption of an organic production system under current European legislation (being the top Italian region in terms of land area and number of operators dedicated to this), but also a considerable delay in defining a possible circular economy model that, through a "bottom up" logic, can define economic-food policy at the local level. The effects of this delay are clearly visible in aspects such as income distribution; population growth; good governance; consumption; greenhouse gases; renewable energy; employment; public debt; etc. This is shown in the first part of Figure 3, in which, with a limited sample of companies, there are still in some cases limited or unacceptable levels of market dependence and sovereignty. Other elements of sovereignty are related to a number of aspects of relational capital, such as the stability of supplier relationships and stakeholder identification. These, together with diversity of production, characterize the local "SFSCs".

\section{Conclusions}

A focal point of this work is the importance of the nexus between organic agriculture and sustainability. In fact, to have a truly sustainable system it is crucial to have a low environmental impact and organic agriculture is one of the best ways of achieving this goal [51]. Another relevant theme in our work is the importance of ethical and economic sectors to be able to achieve completely sustainable agriculture: in fact, at the farms that we assessed there is a close link between preference for the local market, the legality and fairness of worker conditions and a high performance in terms of sustainability.

The study also demonstrated a link between organic farming and the development of local markets. Indeed, the initiatives linked to the "SFSCs" identified enable the reconnection of production and consumption circuits through the development of local farmers' markets and organic farming supported by the community (joint purchasing groups, for example). Within this area of solidarity-based interconnection, a network is developed between families of farmers, certification associations, processors, researchers and local consumers in such a way that local food security is ensured and the wealth produced remains in the community, as has been widely acknowledged at international level. [52]. Active members of "SFSCs" in Sicily and the United Arab Emirates grow and sell various agricultural products-including citrus fruits, vegetables, cereals, fresh and dried fruit, honey, milk, eggs and meat-that reach thousands of consumers.

SAFA has proved to be a powerful tool for measuring sustainability in the two geographical cases considered, but has room for further improvement.

Firstly, it has a very complex structure in terms of the indicators/questions put to the users surveyed. In many cases the survey seemed lengthy and not always sustainable for the business. It is perhaps necessary to provide a simplified version that can be adapted to different sectors and specific purposes (as in our case it was used to analyse food sovereignty) [53].

Secondly, SAFA is limited to photographing the level of sustainability at the specific time of the survey, whereas it has the potential to become a behavioural protocol for businesses wishing to pursue a process aimed at improving their sustainability performance. This would make it possible to support a more accurate survey and to reduce the percentage of responses with " 1 low quality data" scores.

In terms of food sovereignty, several indicators exist within SAFA that directly ("cultural diversity") and indirectly measure this aspect of food security. However, given the importance that this issue has acquired (see the EXPO Milano 2015 declaration) and given the demand for a reorientation of public policies towards food sovereignty and the solidarity economy, the possibility is envisaged within SAFA for a "cultural dimension" of sustainability that is able to assess aspects such as local food production, participatory democratic practices and the creation of value and values. Table 6 therefore shows some possible indicators built on the assumption that food sovereignty can take hold more easily where the existence of SFSCs is recorded and the entrepreneur shows processes of resilience [54]. 
Table 6. Proposal for Supplementary indicators for SAFA on food sovereignty $\left({ }^{a}\right)$.

\begin{tabular}{|c|c|c|}
\hline Perspective & Attribute & Indicator \\
\hline \multirow{5}{*}{ Farm resilience } & land tenure & $\begin{array}{l}\text { proportion of the rented and owned land on } \\
\text { total farm land }\end{array}$ \\
\hline & educational level & $\begin{array}{l}\text { proportion of traditional knowledge on the } \\
\text { total knowledge employed }\end{array}$ \\
\hline & $\begin{array}{l}\text { recovery, restructuring and } \\
\text { maintenance of agricultural } \\
\text { irrigation equipment }\end{array}$ & investments made and/or projects funded \\
\hline & $\begin{array}{l}\text { agricultural diversification } \\
\text { Information exchange systems }\end{array}$ & $\begin{array}{l}\text { new crops and/or crop systems introduced } \\
\text { existence of best practices }\end{array}$ \\
\hline & $\begin{array}{l}\text { multifunctionality and } \\
\text { diversification of activity }\end{array}$ & $\begin{array}{l}\text { proportion of alternative activities } \\
\text { (agrotourism, energy, etc.) }\end{array}$ \\
\hline \multirow{4}{*}{$\begin{array}{l}\text { Social and } \\
\text { relational capital }\end{array}$} & networks of formal relationships & $\begin{array}{l}\text { proportion of the neighbourly relations } \\
\text { in SFSCs }\end{array}$ \\
\hline & networks of informal relationships & $\begin{array}{l}\text { dimension and value of indirect relationships } \\
\text { on local market }\end{array}$ \\
\hline & & farm participation in associations or \\
\hline & network of local relationships & $\begin{array}{l}\text { cooperatives, buying groups, districts of } \\
\text { solidarity, food councils }\end{array}$ \\
\hline \multirow{2}{*}{$\begin{array}{l}\text { Contribution to } \\
\text { quality of life }\end{array}$} & neighbourly relations & $\begin{array}{l}\text { proportion of the surface area for social or } \\
\text { social services, didactics }\end{array}$ \\
\hline & local-scale design & proportion of time spent on total work time \\
\hline
\end{tabular}

$\left({ }^{a}\right)$ Our processing.

As well as these possible additional indicators, on which a debate would be useful, the issue of food sovereignty must be addressed through a participatory process that recognizes the centrality of the geographical area and all its elements, above all in the case of small and medium-sized farms. This political vision contrasts with the principle which holds that it is possible to acquire land on the world market to guarantee food security (for example in other areas of Asia and Africa), since it recognises the right to usage and possession and the reciprocity of this right at international level. This will make it possible to closely link food security and sovereignty to the principles of economic, social, environmental and cultural sustainability.

Work will continue with the objective of: (1) defining, from a technical point of view, indications for lower consumption of resources in the production sectors involved in the survey; (2) for the SFSCs considered, assessing their ability to bring about changes in eating habits and food education, greater attention to product safety and origin and the rediscovery of territories while enhancing the value of their ancient local traditions.

Acknowledgments: This study was carried out thanks to the financial support of the Memorandum of cultural and scientific cooperation between "ABU DHABI DEVELOPMENT GROUP" (United Arab Emirates) and the University of Catania (Luciano Cosentino, scientific coordinator). As part of the Memorandum, in autumn 2015 a research project of a 3-year research doctorate was started at the University of Catania (Sicily, Italy): "A model of sustainable organic production for food security in the United Arab Emirates and in Sicily". The research was designed and implemented in collaboration with IFOAM ABM and FAO.

Author Contributions: The study is the result of full collaboration and therefore the authors accept full responsibility. The true writing of Section 1 is attributable to Salvatore Luciano Cosentino; the Sections 4.2 and 4.3 are attributable to Paolo Guarnaccia; the Sections 2 and 4.1 are attributable to Khalid Butti Al Shamsi; Antonio Compagnoni took care of the survey of organic farms in Sicily and in the United Arab Emirates; the Sections 3, 4.4 and 5 are attributable to Giuseppe Timpanaro.

Conflicts of Interest: The authors declare no conflict of interest. 


\section{References}

1. The Organisation for Economic Co-operation and Development. The Bioeconomy to 2030: Designing a Policy Agenda; OECD: Paris, France, 2009.

2. Di Iacovo, F.; Brunori, G.; Innocenti, S. Le strategie urbane: Il piano del cibo. Agriregionieuropa 2013, 32, 9-16.

3. Di Iacovo, F. Agriculture and social sustainability. In Proceedings of the Congresso Della Società Italiana Degli Economisti Agrari (Sidea), Lecce, Italy, 26-27 September 2014.

4. Foodlinks. Short Food Supply Chains as Drivers for Sustainable Development. Evidence Document; Short Food Supply Chains; Community of Practice; Foodlinks Project; Laboratorio di Studi rurali "Sismondi": Pisa, Italy, 2013; p. 105.

5. Marsden, T.K.; Banks, J.; Bristow, G. Food supply chain approaches: Exploring their role in rural development. Sociol. Rural. 2000, 40, 424-438. [CrossRef]

6. Renting, H.; Marsden, T.; Banks, J. Understanding Alternative Food Networks: Exploring the Role of Short Food Supply Chains in Rural Development. Environ. Plan. A 2003, 35, 393-411. [CrossRef]

7. Seufert, V.; Ramankutty, N.; Foley, J.A. Comparing the yields of organic and conventional agriculture. Nature 2012, 485, 229-232. [CrossRef] [PubMed]

8. Al Qaydi, S. Food Security in the United Arab Emirates; the Role of the State in Overseas Farm Crops Production. Asian J. Agric. Ext. Econ. Sociol. 2014, 3, 569-579.

9. Al Qaydi, S. The Status and Prospects for Agriculture in the United Arab Emirates (UAE) and their Potential to Contribute to Food Security. J. Basic Appl. Sci. 2016, 12, 155-163. [CrossRef]

10. Shahin, S.M.; Salem, M.A. Food security in the United Arab Emirates (UAE): The great competition between the agricultural and forestry sector on irrigation resources. In Proceedings of the International Research Conference on Science, Health \& Medicine (IRCSHM), Dubai, UAE, 15-16 October 2014.

11. Shahin, S.M.; Salem, M.A. Food Security in the United Arab Emirates (UAE): The Great Competition between the Agricultural and Forestry Sector on Irrigation Resources. Int. J. Res. Sci. 2015, 1, 19-23. [CrossRef]

12. FAO; IFAD; UNICEF; WFP; WHO. The State of Food Security and Nutrition in the World 2017. Building Resilience for Peace and Food Security; FAO: Rome, Italy, 2017.

13. FiBL; IFOAM. The World of Organic Agriculture Statistics and Emerging Trends; Willer, H., Yussefi, M., Sorensen, N., Eds.; Research Institute of Organic Agriculture (FiBL): Frick, Switzerland; International Federation of Organic Agriculture Movements (IFOAM): Bonn, Germany, 2017.

14. Shahin, S.; Salem, M.A. The Challenges of Water Scarcity and the Future of Food Security in the United Arab Emirates (UAE). Natl. Resour. Conserv. 2015, 3, 1-6. [CrossRef]

15. Timpanaro, G.; Foti, V.T.; Spampinato, D. Organic Farming in Sicily: Analysis and perspectives through the main Productive Chains. Qual. Access Success 2013, 14, 157-164.

16. Foti, V.T.; Scuderi, A.; Timpanaro, G. The economy of the common good: The expression of a new sustainable economic model. Qual. Access Success 2017, 18 (Suppl. S2), 206-214.

17. Marasteanu, I.J.; Jaenicke, E.C. Economic Impact of Organic Agriculture Hotspots in the United States. Working Paper. 2016. Available online: http:/ / ssrn.com/abstract=2765969 (accessed on 19 October 2017).

18. Marasteanu, I.J.; Jaenicke, E.C. Hotspots and Spatial Autocorrelation in Certi ed Organic Operations in the United States. Agric. Resour. Econ. Rev. 2016, 45, 485-521. [CrossRef]

19. Coppo, G.; Stemp, S.; Reho, M. Urban food strategies and plans: Considerations on the assessment construction. City Territ. Archit. 2017, 4, 1-7. [CrossRef]

20. Galli, F.; Smith, J.; Brunori, G.; Barling, D. Global, Regional and Local food chains: An assessment of sustainability performance of wheat to bread chains across Italy and the UK. In Proceedings of the Second International Conference on Agriculture in an Urbanizing Society Reconnecting Agriculture and Food Chains to Societal Needs, Rome, Italy, 14-17 September 2015.

21. Brunori, G.; Galli, F.; Barjolle, D.; Van Broekhuizen, R.; Colombo, L.; Giampietro, M.; Kirwan, J.; Lang, T.; Mathijs, E.; Maye, D.; et al. Are local food chains more sustainable than global food chains? Considerations for assessment. Sustainability 2016, 8, 449. [CrossRef]

22. Gaboury-Bonhomme, M.È. Society oriented and sustainable agriculture: An emerging paradigm in Québec (Canada)? In Proceedings of the Second International Conference on Agriculture in an Urbanizing Society Reconnecting Agriculture and Food Chains to Societal Needs, Rome, Italy, 14-17 September 2015. 
23. Steigberger, E. Sustainable food systems: Community Supported Agriculture a socialecological analysis)? In Proceedings of the Second International Conference on Agriculture in an Urbanizing Society Reconnecting Agriculture and Food Chains to Societal Needs, Rome, Italy, 14-17 September 2015.

24. Grando, S.; Brunori, G.; Colombo, L. Quality, Technology, Sovereignty. Discourses on Food Security in Italy. In Proceedings of the Second International Conference on Agriculture in an Urbanizing Society Reconnecting Agriculture and Food Chains to Societal Needs, Rome, Italy, 14-17 September 2015.

25. Agarwal, B. Food sovereignty, food security and democratic choice: Critical contradictions, difficult conciliations. J. Peasant Stud. 2014, 41, 1247-1268. [CrossRef]

26. Rossi, A.; Brunori, G. Le pratiche di consumo alimentare come fattori di cambiamento. Il caso dei Gruppi di Acquisto Solidale. Agriregionieuropa 2011, 27, 1-8.

27. Tregear, A. Progressing knowledge in alternative and local food networks: Critical reflections and a research agenda. J. Rural Stud. 2011, 27, 419-430. [CrossRef]

28. Chiffoleau, Y. From Politics to Co-operation: The Dynamics of Embeddedness in Alternative Food Supply Chains. Sociol. Rural. 2009, 49, 218-235. [CrossRef]

29. Schader, C.; Grenz, J.; Meier, M.S.; Stolze, M. Scope and precision of sustainability assessment approaches to food systems. Ecol. Soc. 2014, 19, 42. [CrossRef]

30. Filippini, R.; Marraccini, E.; Houdart, M.; Bonari, E.; Lardon, S. Food production for the city: Hybridization of farmers' strategies between alternative and conventional food chains. Agroecol. Sustain. Food Syst. 2016, 40, 1058-1084. [CrossRef]

31. Altieri, M.A. Agroecology, small farms and food sovereignity. Mon. Rev. 2009, 61, 102-111. [CrossRef]

32. Altieri, M.A.; Nicholls, C.I.; Ponti, L. Agroecologia Sovranità Alimentare e Resilienza dei Sistemi Produttivi; Fondazione Giangiacomo Feltrinelli: Milano, Italy, 2015; ISBN 978-88-6835-214-1.

33. Badgley, C.; Moghtader, J.; Quintero, E.; Zakem, E.; Chappell, M.J.; Aviles-Vazquez, K.; Samulon, A.; Perfecto, I. Organic agriculture and the global food supply. Renew. Agric. Food Syst. 2007, 22, 86-108. [CrossRef]

34. Pretty, J.; Morrison, J.I.L.; Hine, R.E. Reducing food poverty by increasing agricultural sustainability in the development countries. Agric. Ecosyst. Environ. 2003, 95, 217-234. [CrossRef]

35. UNCTAD/UNEP. Organic Agriculture and Food Security in Africa; UNCTAD/UNEP: New York, NY, USA, 2008. Available online: http:/ / www.unctad.org/en/docs/ditcted200715_en.pdf (accessed on 26 October 2017).

36. Food and Agriculture Organization. SAFA Sustainability Assessment of Food and Agriculture Systems Tool User Manual Version 2.2.40; FAO: Rome, Italy, 2014; E-ISBN 978-92-5-108597-4.

37. Food and Agriculture Organization. SAFA Sustainability Assessment of Food and Agriculture Systems Indicators; FAO: Rome, Italy, 2013.

38. Schmid, O.; Brunori, G.; Galli, F.; van de Graaf, P.; Prior, A.; Ruiz, R. Contribution of short food supply chains to sustainability and health. In Proceedings of the 11th European IFSA Symposium, Berlin, Germany, 1-4 April 2014.

39. Koohafkan, P.; Altieri, M.A.; Gimenez, E.H. Green Agriculture: Foundations for Biodiverse, Resilient and Productive Agricultural Systems. Int. J. Agric. Sustain. 2012, 10, 61-75. [CrossRef]

40. Godfray, H.C.; Beddington, J.R.; Crute, I.R.; Haddad, L.; Lawrence, D.; Muir, J.F.; Pretty, J.; Robinson, S.; Thomas, S.M.; Toulmin, C. Food security: The challenge of feeding 9 billion people. Science 2010, 327, 812-818. [CrossRef] [PubMed]

41. Food and Agriculture Organization. Labeling and Certification; FAO Fisheries and Aquaculture Department: Rome, Italy, 2013.

42. Food Marketing Research \& Information Center. Handbook for Introduction of Food Traceability Systems (Guidelines for Food Traceability); Food Marketing Research and Information Center: Tokyo, Japan, 2007. (In Japanese)

43. European Commission. Europe 2020. A Strategy for Smart, Sustainable and Inclusive Growth. Communication from the Commission; Com (2010) 2020 Final; European Commission: Brussels, Belgium, 2010.

44. The Organisation for Economic Co-operation and Development. LEED Program: Local Economic and Employment Development; OECD: Paris, France, 2013.

45. United Nations UN. Universal Declaration of Human Rights (Articles 17 and 25); United Nations UN: Paris, France, 2013. 
46. Timpanaro, G.; Foti, V.T. Social capital and innovation in agriculture: The case of micropropagation in the Italian nursery industry. Agric. Econ. Rev. 2016, 17, 343-353.

47. Nyeleni. Food Sovereignty: A Right for All. In Proceedings of the NGO /CSO Forum for Food Sovereignty, Rome, Italy, 8-13 June 2002.

48. United Nations Capital Development Fund. Procurement for Local Development, a Guide to Best Practice in Local Government Procurement in Least Developed Countries; United Nations Capital Development Fund: New York, NY, USA, 2013.

49. FAO/INRA. Innovative Markets for Sustainable Agriculture-How Innovations in Market Institutions Encourage Sustainable Agriculture in Developing Countries; Loconto, A., Poisot, A.S., Santacoloma, P., Eds.; FAO/INRA: Rome, Italy, 2016.

50. Timpanaro, G.; Scuderi, A.; Foti, V.T.; Lo Giudice, V. The Social Relationships' Effectiveness of "Agrisocial" Farms: A Model of Sustainable Local Development. Rivista di Studi sulla Sostenibilità 2015, 18, 99-116.

51. Consultative Group on International Agricultural Research. Achieving Food Security in the Face of Climate Change; Final Report from the Commission on Sustainable Agriculture and Climate Change; CGIAR: Montpellier, France, 2012; Available online: http:/ /ccafs.cgiar.org/commission/reports (accessed on 15 November 2017).

52. Van der Ploeg, J.D. The New Peasantries: New Struggles for Autonomy and Sustainability in an Era of Empire and Globalization; Earthscan: London, UK, 2009; 356p.

53. Jawtusch, J.; Schader, C.; Stolze, M.; Baumgart, L.; Niggli, U. Sustainability Monitoring and Assessment Routine: Results from Pilot Applications of the FAO SAFA Guidelines; Research Institute of Organic Agriculture FiBL: Frick, Switzerland, 2014.

54. Bachmann, L.; Cruzada, E.; Wright, S. Food Security and Farmer Empowerment: A Study of the Impacts of Farmer-Led Sustainable Agriculture in the Philippines; Masipag-Misereor: Los Banos, Philippines, 2009.

(C) 2018 by the authors. Licensee MDPI, Basel, Switzerland. This article is an open access article distributed under the terms and conditions of the Creative Commons Attribution (CC BY) license (http:/ / creativecommons.org/licenses/by/4.0/). 